\title{
Effect of Beet Powder (Beta Vulgaris L) with Fe Supplementation on Increasing Hemoglobin, Hematocrit, and Erythrocyte Levels in Pregnant Women with Anemia
}

\author{
Hilma Triana*, Suharyo Hadisaputro, Masrifan Djamil \\ Semarang Health Polytechnic, Central Java, Indonesia \\ *trianahilma@gmail.com
}

\begin{abstract}
Anemia in pregnancy is a condition where the hemoglobin level in pregnant women $<11.0$ $\mathrm{gr} / \mathrm{dL}$. Anemia in pregnancy can cause disruption of fetal development, risk of low birth weight and premature birth. Beetroot one of the herbs can increase hemoglobin, hematocrit and erythrocyte levels.

This research aimed to prove the effect of beetroot extract increase hemoglobin, hematocrit level and erythrocytes number of pregnant women with anemia who were receiving Fe supplementation. This research was Quasy Experiment with a pre-test-post-test with control group design. Sample this research was 30 pregnant women, that were divided into 2 groups : the intervention group who were given beet with Fe supplementation $(n=15)$ and the control group was given Fe tablets $(n=15)$.

Supplementation of beetroot to a pregnant women with anemia who were recieived $\mathrm{Fe}$ supplementation could increase hemoglobin levels $(\mathrm{p}=0,000)$, hematocrit levels $(\mathrm{p}=$ $0,000)$, number of erythrocytes $(\mathrm{p}=0.001)$, so there were significant differences in mean delta hemoglobin levels, hematocrit, and erythrocyte counts. There were differences in hemoglobin and erythrocyte levels in the intervention and control groups before and after treatment.

Supplementation of 8 gram beetroot powder for 14 days to pregnant mother with anemia who were receive $\mathrm{Fe}$ tablets could increase hemoglobin and hematocrit levels, and number of erythrocytes.
\end{abstract}

Keywords : Beet Powder, Powder, Fe Supplementation, Pregnant Women 


\section{STRADA Jurnal Ilmiah Kesehatan}

DOI: $10.30994 /$ sjik.v9i2.354

ISSN: 2252-3847 (print); 2614-350X (online)

Vol.9 No.2 November 2020 Page.893-899

\section{BACKGROUND}

Anemia during pregnancy according to the CDC (Center for Disease Control and Prevention) is a condition where the hemoglobin level in pregnant women is less than 11.0 $\mathrm{g} / \mathrm{dl}$ in trimesters I and III, or where the amount of hemoglobin level is less than $10.5 \mathrm{~g} /$ $\mathrm{dl}$ in the second trimester. ${ }^{1}$ Pregnancy is a period in which there is an increase in physiological iron necessary, which is if iron deficiency during pregnancy will cause the risk of anemia in pregnancy which results in disruption of fetal development, risk of low birth weight and premature birth. ${ }^{2}$

World Health Organization (WHO), globally the prevalence of anemia in pregnant women worldwide is $41.8 \% .^{3}$ Anemia in pregnant women in Indonesia based on Riskesdas in 2018 was $48.9 \%$, where an increase of $11.8 \%$ compared to 2013 which amounted to $37.1 \%$. In Indonesia, anemia in pregnant women mostly occurs at the age of 15-24 years as much as $86.4 \%$, at the age of $25-34$ as much as $33.7 \%$, as much as $33.6 \%$ occurs at age 35 44 years and as low as $24 \%$ at the age of $45-54$ years. $^{4}$

Anemia in pregnant women often occurs due to iron deficiency because in pregnant women there is an increase in iron needs doubled due to increased blood volume without plasma volume expansion. ${ }^{5}$ Erythrocytes are a component of cells in the blood that function as a medium that carries hemoglobin which will carry oxygen from the lungs to the tissues. A pregnant woman who has anermia does not have enough hemoglobin in her body. ${ }^{6}$ Iron is needed by the body to forms hemoglobin in erythrocytes in the bone marrow, to compensate for the small amount of iron that is constantly being expelled by the body, and to compensate for iron loss due to bleeding and lactation for secretion milk. ${ }^{7}$

Beetroot, a type of amaranthaceae plant containing high iron, nearly $7 \%$ which is very good to help in the formation of a baby's brain and overcome anemia. ${ }^{8}$ This study aims to prove the effect of beetroot powder with supplementing $\mathrm{Fe}$ on the levels of hemoglobin, hematocrit and erythrocytes for pregnant women.

\section{METHOD}

This type of research is a Quasy Experiment with a pre-test-post-test with control group design. The sample in this study amounted to 30 pregnant women who were divided into 2 groups, namely the intervention group $(n=15)$ and the control group $(n=15)$. The subjects in this study were third trimester pregnant women (28-36 weeks gestational age) in the work area of Welahan I Public Health Center, Jepara Regency.

The sampling technique used was purposive sampling, with inclusion criteria of pregnant women aged 20-35 years, pregnant women with a minimum pregnancy interval of 2 years, number of children <4, pregnant women with mild anemia $\mathrm{Hb}<11 \mathrm{gr} \%$ / dL, and willing to be a research respondent.

The intervention group was given 8 gram beetroot powder with Fe supplementation once a day for 14 days, while the control group was given Fe tablets once a day for 14 days. All study respondents provided informed consent and were willing to participate in the study voluntarily. This study was approved by the Ethics Committee of Moewardi Hospital Surakarta with the number 053 / I / HREC / 2020.

The instruments used in this study were respondent characteristic questionnaires and daily intervention checklist tables while for measuring hemoglobin, hematocrit and erythrocyte counts using a hematology analyzer. The test used is the Paired Sample T-Test and Independent T-Test. 


\section{RESULT}

A. Description of Beet Powder Powder with Fe Supplementation

Table 1. Hemoatological survey before and after beetroot powder with $\mathrm{Fe}$ Supplementation

\begin{tabular}{llcccc}
\hline & & Min & Max & Mean & Std Deviation \\
\hline Hemoglobin & Pretest & 8,60 & 10,20 & 10,1267 & 0,635 \\
Levels & Posttest & 10,90 & 13,30 & 11,8400 & 0,786 \\
Hematocrit & Pretest & 26,00 & 26,90 & 31,9400 & 2,870 \\
Levels & Posttest & 38,10 & 38,40 & 33,3467 & 2,939 \\
Erythrocyte & Pretest & 2,87 & 2,96 & 3,7267 & 0,345 \\
Levels & Posttest & 4,24 & 4,71 & 3,9300 & 0,467 \\
\hline
\end{tabular}

*Paired T-Test

Based on the table 1 shows the increase in hemoglobin levels is minimal before and after beetroot powder intervention with Fe supplementation is $2.3 \mathrm{gr} / \mathrm{dL}$ and 3.1 $\mathrm{gr} / \mathrm{dL}$. The minimum value of hemogobin levels before the intervention is $8.60 \mathrm{gr} /$ $\mathrm{dL}$ while the minimum value after the intervention is $10.90 \mathrm{gr} / \mathrm{dL}$. The maximum value in the pretest hemoglobin level is $10.20 \mathrm{gr} / \mathrm{dL}$ and after the intervention is $13.30 \mathrm{gr} / \mathrm{dL}$.

The minimum value on hematocrit levels before intervention is 26.00 and the minimum value after intervention is $38.10 \%$, while the maximum value before intervention is $26.90 \%$ and after intervention is $38.40 \%$. Hematocrit levels had a minimum increase before intervention of $12.1 \%$ and a maximum increase of $11.5 \%$. Increasing the minimum value of erythrocytes $1.37 / \mathrm{uL}$ and the maximum value of $1.75 / \mathrm{uL}$. The minimum pretest value is $2.87 / \mathrm{uL}$ and posttest is $4.24 / \mathrm{uL}$. The maximum value of pretest is $2.96 / \mathrm{uL}$ and posttest is $4.71 / \mathrm{uL}$.

\section{B. Description of Fe Tablets}

Table 2. Hemoatological survey before and after Fe Supplementation

\begin{tabular}{llcccc}
\hline & & Min & Maks & Mean & Std Deviation \\
\hline Hemoglobin & Pretest & 8,00 & 10,90 & 10,2667 & 0,774 \\
Levels & Posttest & 8,80 & 11,80 & 10,5267 & 0,854 \\
Hematocrit & Pretest & 27,80 & 37,90 & 31,7267 & 2,562 \\
Levels & Posttest & 26,90 & 39,30 & 32,4333 & 3,167 \\
Erythrocyte & Pretest & 3,30 & 3,14 & 3,8507 & 0,451 \\
Levels & Posttest & 4,91 & 5,04 & 3,9233 & 0,525 \\
\hline
\end{tabular}

*Paired T-Test

In the provision of Fe tablet intervention, the minimum increase in the value of hemoglobin is $0.80 \mathrm{gr} / \mathrm{dL}$ and the maximum increase in hemoglobin level is $0.90 \mathrm{gr} /$ dL. At a minimum value of hematocrit levels there was no increase, but a decrease of 0.9 , and a maximum increase in the value of hematocrit levels that is $1.4 \%$. The minimal increase in erythrocytes in Fe tablet intervention was $1.61 / \mathrm{uL}$ and the maximum increase was $1.91 / \mathrm{uL}$.

The minimum value of pretest hemoglobin level is $8.00 \mathrm{gr} / \mathrm{dL}$ and posttest is $8.80 \mathrm{gr} / \mathrm{dL}$, while the maximum value at pretest is $10.90 \mathrm{gr} / \mathrm{dL}$ and the maximum value at posttest is $11.80 \mathrm{gr} / \mathrm{dL}$. In the hematocrit level there is a minimum value 


\section{STRADA Jurnal Ilmiah Kesehatan}

DOI: $10.30994 /$ sjik.v9i2.354

ISSN: 2252-3847 (print); 2614-350X (online)

Vol.9 No.2 November 2020 Page.893-899

before the intervention that is $27.80 \%$ and after the intervention that is $26.90 \%$, while the maximum value before the intervention is $37.90 \%$ and after the intervention that is $39.30 \%$. In erythrocytes the minimum pretest value is $3.30 / \mathrm{uL}$ and post test is 4.91 / $\mathrm{uL}$ while the maximum value at pre and post is $3.14 / \mathrm{uL}$ and $5.04 / \mathrm{uL}$.

Changes in hemoglobin, hematocrit levels, and the amount of erythrocytes can be seen in the graph below:

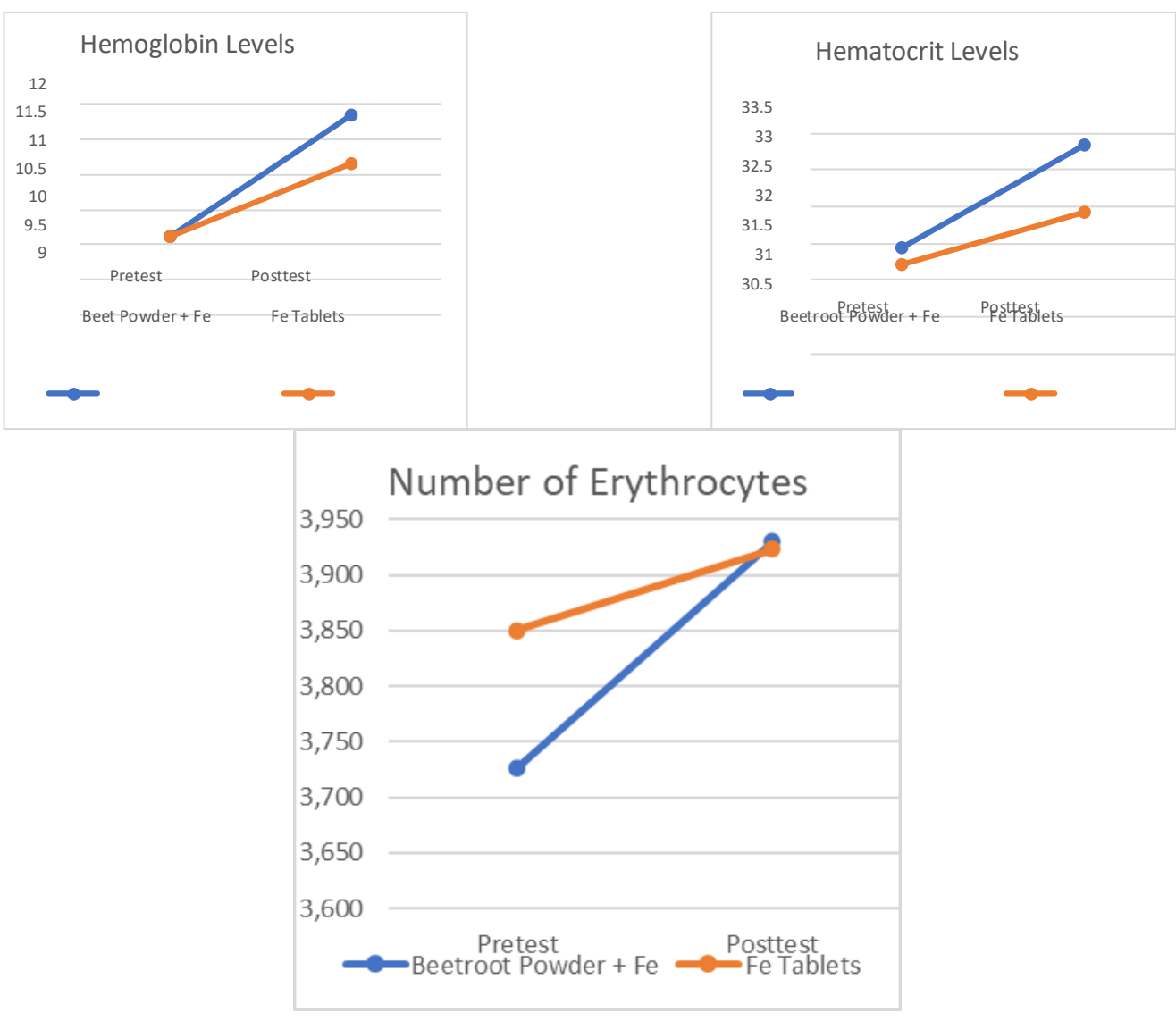

C. Comparison of Beetroot Powder with Fe and Tablet Fe Supplementation

Table 3. The comparison of beetroot powder with Fe supplementation and Fe tablets

\begin{tabular}{lllrrr}
\hline & Intervention & $\mathrm{N}$ & Mean & Std Deviation & p-value \\
\hline Hemoglobin & Beet Powder + Fe & 15 & 1,713 & 0,499 & 0,000 \\
Difference & Fe Tablets & 15 & 0,260 & 0,567 & 0,098 \\
\hline Hematocrit & Beet Powder + Fe & 15 & 1,406 & 1,068 & 0,000 \\
Difference & Fe Tablets & 15 & 0,706 & 1,404 & 0,072 \\
\hline Erythrocyte & Beet Powder + Fe & 15 & 0,203 & 0,176 & 0,000 \\
Difference & Fe Tablets & 15 & 0,072 & 0,154 & 0,089 \\
\hline
\end{tabular}

Indpendent T-Test

The results of table 3 . the $p$-value of hemoglobin, hematocrit and erythrocyte levels in beetroot powder interventions with Fe supplementation is $0,000<0.05$, meaning that there are significant differences between the average levels of hemoglobin, hematocrit and erythrocytes before and after intervention. In the Fe tablet group the $p$-value for hemoglobin was $0.098>0.05$ where there was no significant 


\section{STRADA Jurnal Ilmiah Kesehatan}

DOI: $10.30994 /$ sjik.v9i2.354

ISSN: 2252-3847 (print); 2614-350X (online)

Vol.9 No.2 November 2020 Page.893-899

difference between the average before and after the Fe tablet intervention. The $p$-value of hematocrit and erythrocyte levels in Fe tablet intervention is 0.072 and 0.089 so there is no significant difference between the average before and after the intervention is given.

\section{DISCUSSION}

1. The Effect of Beet Powder with Fe Supplementation on Hemoglobin, Hematocrit and Erythrocyte Levels in Pregnant Women with Anemia

Beetroot are one of the plants that can be managed into various processed such as ice cream, jelly, donuts and others. Beetroot tastes bitter when it is made into ice cream, and when the higher the beetroot juice is made into jelly it will be groundscented. This makes many pregnant women didn't like beetroot. ${ }^{9}$

Along with the development of modernization which demands practicality and ease in the use of traditional medicines, so various efforts have been made to develop the use of guava plants as medicinal plants in practical dosage forms. One alternative dosage form is effervescent powder. ${ }^{10}$ That reasons, makes researchers make innovations to make fresh beetroot into beetroot powder.

Pregnant women with anemia getting beet powder for 14 days with iron supplementation showed changes in hemoglobin levels, hematocrit and erythrocyte counts. Giving beetroot by the powder method to pregnant women is safer than extracts. Powder is a dry mixture of medicinal substances or crushed chemicals, intended for oral use or external use. The powder does not use alcohol such as butanol, ethanol and metanol in the manufacturing process, meanwhile the extraction process using butanol, ethanol and methanol in processing to become extracts. ${ }^{11}$

Giving 8 grams of beet root powder with Fe supplementation for 14 days can increase hemoglobin, hematocrit and erythrocyte levels, where an increase in hemoglobin level is $1.713 \mathrm{gr} \% \mathrm{dL}$, an increase in hematocrit levels of $1.406 \%$ and erythrocytes by $0.203 / \mathrm{uL}$. This study was supported by Suryandari and Ossie (2015) where the provision of $500 \mathrm{~mL}$ beetroot juice was added by consuming Fe tablets for 7 days which was as much as $0.6 \mathrm{gr} \% / \mathrm{dL}$, where hemoglobin levels before the intervention were $9.70 \mathrm{gr} \%$ / $\mathrm{dL}$ and increased to $10.30 \mathrm{gr} \%$ / dL after being given the intervention of beetroot juice $500 \mathrm{~mL}$ with Fe tablets. ${ }^{8}$

Beetroot can increase hemoglobin levels as evidenced by the study of Suci Setyiyaningsih, et al in Wonorojo Village, where there is an increase in hemoglobin levels in pregnant women with anemia before given a combination of beet juice and lemon with fe tablets at an average of $10.25 \mathrm{~g} / \mathrm{dl}$, after being given a combination of beet and lemon juice with fe tablets an average of $11.35 \mathrm{~g} / \mathrm{dl}$, or an average increase of $1.1 \mathrm{~g} / \mathrm{dL} .{ }^{12}$

This plant has the Latin name is Beta Vulgaris $L$ has uses for pregnant women such as folic acid $34 \%$ in the process of growth and repair of damaged cells, $13.6 \%$ fiber to prevent pregnant women from experiencing constipation, iron $7.4 \%$ as a metabolism energy and the immune system and $10.2 \%$ vitamin $\mathrm{C}$ as tissue repair and normalizes blood vessels and helps in the absorption of iron in the body. ${ }^{13}$

The results of this study indicate that administration of beetroot powder with iron supplementation can increase hemoglobin levels, hematocrit and the number of erythrocytes in pregnant women with anemia. 


\section{STRADA Jurnal Ilmiah Kesehatan}

DOI: $10.30994 /$ sjik.v9i2.354

ISSN: 2252-3847 (print); 2614-350X (online)

Vol.9 No.2 November 2020 Page.893-899

2. Effect of Fe tablets on hemoglobin, hematocrit and erythrocyte levels in pregnant women with anemia

In this study it was found that hemoglobin levels that were only given Fe tablets only increased by $0.260 \mathrm{gr} \%$ / dL, an increase in hematocrit levels of $0.706 \%$ and an increase in erythrocytes around $0.072 / \mathrm{uL}$. In the statistical test using independent $t$ test, the $p$-value of hemoglobin, hematocrit and erythrocyte values is $>0.05$, so there is no significant difference between the average before and after the intervention is given.

Based on the research Suryandari and Ossie with titled Comparison of Increased $\mathrm{Hb}$ Levels in Pregnant Women who were given Fe with $\mathrm{Fe}$ and Beets in the Work Area of South Purwokerto Public Health Center, where there was no increase in hemoglobin levels in pregnant women who were stabbed with added blood tablets, but experienced a decrease as much as $0.2 \mathrm{gr} \%$ / dL where the average value before being given the intervention is $11.4667 \mathrm{gr} \% / \mathrm{dL}$ and after being given the intervention it becomes $11.33267 \mathrm{gr} / \mathrm{dL}{ }^{8}$ The provision of blood-added tablets for pregnant women has been regulated by the government in the Republic of Indonesia Minister of Health Regulation No. 88 of 2014 and the Republic of Indonesia Minister of Health Regulation No. 43 of 2016. In both regulations states that blood-added tablets must be given to women of reproductive age and pregnant women and especially for pregnant women must obtain at least 90 tablets of added blood during pregnancy. ${ }^{14,15}$

However, Fe tablets can cause constipation which makes many pregnant women reluctant to consume Fe tablets during pregnancy. This has been proven in Susani Hayati's research: pregnant women who do not routinely consume Fe tablets have more constipation, namely 20 people (87\%) compared to those who have constipation only 3 people (13\%), while pregnant women who routinely consume Fe tablets more many experienced constipation by $52.4 \%$ compared to mothers who did not experience constipation by $47.6 \% .^{16}$

Consuming Fe tablets routinely causes fecesl color to become black and hard, thus causing constipation in pregnant women. This is coupled with the relaxation of the small muscles of the large intestine due to an increase in the hormone progesterone, enlargement and pressure on the stomach caused by enlargement of the uterus, making defecation less rare, the amount of stool decreases and making its consistency dry and hard. ${ }^{17}$

In a study so that pregnant women given blood-added tablets didn't have much effect on hemoglobin levels, hematocrit and erythrocyte counts in pregnant women compared to pregnant women who were given beetroot powder with $\mathrm{Fe}$ supplementation.

\section{CONCLUSION}

Supplementation of 8 gram beetroot powder for 14 days to pregnant mother with anemia who were receive $\mathrm{Fe}$ tablets could increase hemoglobin and hematocrit levels, and number of erythrocytes.

Society or pregnant women can use beetroot as a holistic treatment and nonpharmacological treatment in the effort and prevention of anemia in pregnant women.

\section{REFERENCES:}

1. Cunningham F G. Physilogy of Pregnancy in William Obstetric. 21 edition. Jakarta: EGC, 2013. 


\section{STRADA Jurnal Ilmiah Kesehatan}

DOI: $10.30994 /$ sjik.v9i2.354

ISSN: 2252-3847 (print); 2614-350X (online)

Vol.9 No.2 November 2020 Page.893-899

2. Id EAS, Baumgartner J, Malan L, et al. Maternal Iron-Deficiency is Associated with Premature Birth and Higher Birth Weight Despite Routine Antenatal Iron Supplementation in an Urban South African Setting: The NuPED Prospective Study. PLoS One 2019; 3: 1-21.

3. World Health Organization. New Guidelines On Antenatal Care For A Positive Pregnancy Experience. World Health Organization, http://www.who.int/reproductivehealth/news/antenatal-care/en/ (2016, accessed 1 January 2017).

4. Riskesdas. Hasil Utama Riskesdas 2018. Kementeri Kesehat Badan Penelit dan Pengemb Kesehat. Epub ahead of print 2018. DOI: 1 Desember 2013.

5. Annisa K, Latifah. Pemberian Tablet Zat Besi (FE) Pada Ibu Hamil di Posyandu Mawar Berduri RT 05 Kelurahan Tuan Kentang Kecamatan Jakabaring Kota Palembang. J Pengabdi Masy Kebidanan 2020; 2: 1-8.

6. Proverawati, A,\&Asfuah S. Buku Ajar Gizi Untuk Kebidanan. Yogyakarta: Nuha Medika, 2009.

7. Gaw A, Michael J., A.C R, et al. Biokimia Klinis. Jakarta: EGC, 2012.

8. Suryandari AE dan $\mathrm{OH}$. Perbandingan Kenaikan Kadar Hb pada Ibu Hamil yang diberi Fe dengan Fe dan Buah Bit di Wilayah Kerja Puskesmas Purwokerto Selatan. $J$ Kebidanan 2015; VII: 36-47.

9. Chairuni A, Sari PM, Rusnaini. Effect Of Beetroot Extract (Beta Vulgaris L) and CMC (Carboxyl Methyl Cellulose) Concentration on Ice Cream Quality. Serambi J Agric Technol 2019; 1: 80-91.

10. Christina S, Diana VE. Formulasi Sediaan Serbuk Effervescent Sari Buah Jambu Biji (Psidium Guajava). J teh Pharm World 2016; 1: 7-14.

11. Kemeterian Kesehatan Republik Indonesia. Farmakope Indonesia. Edisi V. Jakarta: Direktorat Jendral Bina Kefarmasian dan Alat Kesehatan, 2014.

12. Setyiyaningsih S, Widayati, Wahyu Kritiningrum. Keefektifan Jus Buah Bit dan Lemon dalam Kenaikan Kadar HB. J Kebidanan 2020; 6: 71-76.

13. Wijayakusuma H. Ramuan Herbal Penurun Kolestrol. I. Jakarta: Niaga Swadaya, 2008.

14. Kementerian Kesehatan Republik Indonesia. Peraturan Menteri Kesehatan Republik Indonesia Nomor 88 Tahun 2014 Tentang Standar Tablet Tambah Darah Bagi Wanita Usia Subur dan Ibu Hamil. Jakarta, 2014.

15. Kementerian Kesehatan Republik Indonesia. Peraturan Menteri Kesehatan No.43 Tahun 2016 tentang Standar Pelayanan Minimal Bidang Kesehatan. 31 Agustus 2016.

16. Susani H. Pengaruh Konsumsi Tablet Fe dengan Kejadian Konstipasi pada Ibu Hamil di Puskesmas Payung Sekaki Pekanbaru. J Med Usada 2020; 3: 15-19.

17. Naviri D. Buku Pintar Ibu Hamil. Jakarta: Elex Media Komputindo, 2011. 